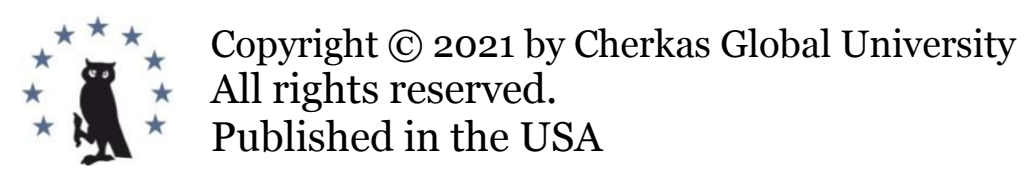

European Journal of Contemporary Education

E-ISSN 2305-6746

2021. 10(4): 868-878

DOI: $10.13187 /$ ejced.2021.4.868

https://ejce.cherkasgu.press

IMPORTANT NOTICE! Any copying, reproduction, distribution, republication (in whole or in part), or otherwise commercial use of this work in violation of the author(s) rights will be prosecuted in accordance with international law. The use of hyperlinks to the work will not be considered copyright infringement.

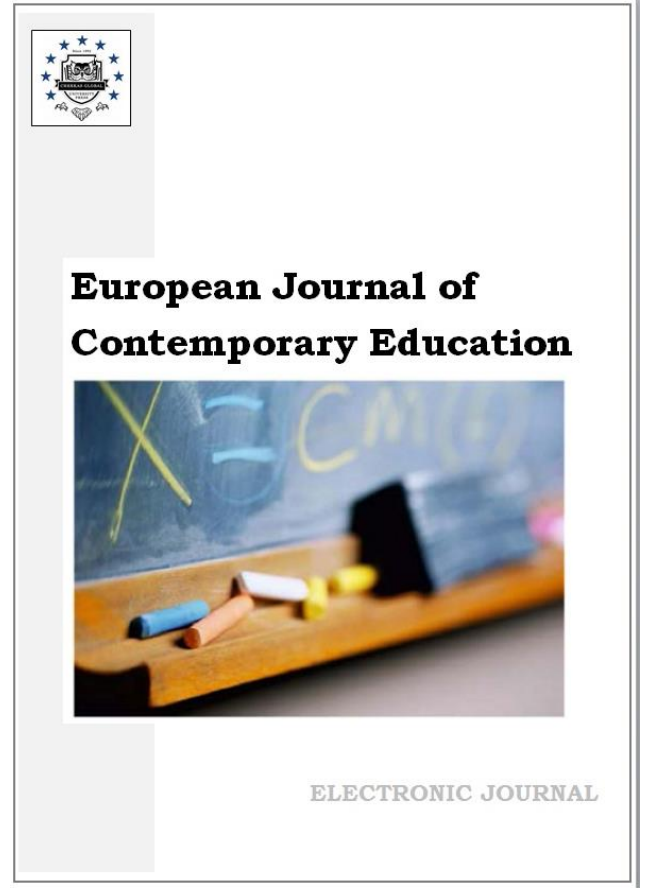

\title{
Improving Students' Independent Work under Teacher's Supervision during Foreign Language Learning at the University
}

\author{
Gulmira Baideldinova ${ }^{a},{ }^{*}$, Bakhytgul Zhetpisbayeva a, Bikesh Ospanova ${ }^{\mathrm{b}}$, Dana Tleumbetova ${ }^{\mathrm{b}}$ \\ a Buketov Karaganda University, Karaganda, Kazakhstan \\ ${ }^{\mathrm{b}}$ Karaganda Technical University, Karaganda, Kazakhstan
}

\begin{abstract}
Studying foreign languages contributes to introducing future specialists to universal humanitarian values, confident inclusion into the global community and successful professional adaptation. First-class higher education is instrumental in achieving this goal. The study deals with the techniques of improving the structure of the students' independent work under the teacher's supervision when studying a foreign language in a technical university. Factual material can be applied in the analysis of the methods used to organize the students' independent work with the teacher and contribute to the students' increased interest in additional education that will expand the students' horizons and promote the development of the diagnostic thinking process. The study provides the basis for giving several recommendations for improving the structure of the students' independent work on the foreign language under the teacher's supervision: apply modern innovative methods that activate the students' cognitive activity; implement the technique of organizing the students' independent work on the foreign language under the teacher's supervision and the algorithms for its application.

Keywords: language training, foundations of organizing independent work, methodological guidelines, professionally-oriented texts, university.

\section{Introduction}

The language training of specialists is becoming an integral guarantee of employment and an indicator of a specialist's competitiveness in the global labor market. Today one needs proactive and independent specialists who can constantly improve their professional skills, characterized by high sensitivity, curiosity, a willingness to quickly update knowledge and a wide range of skills

\footnotetext{
* Corresponding author

E-mail addresses: gulmira.baideldinova@gmail.com (G. Baideldinova)
} 
(Zein, 2017). In this regard, teachers of a foreign language are faced with the crucial task of forming students' skills and abilities of independent work on learning the language, extending their language knowledge and communicative culture (Filippello et al., 2019). At the same time, the emphasis should be transferred from direct teaching of a foreign language to the study of a foreign language, the actualization of the students' independent cognitive activity which allows them to consciously navigate an endlessly changing information space (Lou et al., 2012). Therefore, one of the key tasks of language training is to provide pedagogical conditions for organizing independent work for the students' self-education, self-fulfillment and self-development (Ayodele, Adebiyi, 2013). Having not only specific knowledge but also the ability to study independently, find the necessary information, students acquire the chance to expand the boundaries of their own development (Sharok, 2018; Mendezabal, 2013).

In this article, we attempt to describe the technique for organizing students' independent work under the teacher's supervision (SIWT) during the language training based on the formation of an educational system aimed at increasing the level of self-education and creative acquisition of knowledge by students (Mutsotso, Abenga, 2010; Samuelson, Litzler, 2016).

The organization of SIWT in a technical university, as in other universities, is aimed at the formation of independent activity, developing the skills and abilities for the rational acquisition of useful information. Therefore, university teachers thoroughly prepare for the organization of SIWT, starting with the definition of goals and objectives, the development of various tasks according to the topic of the lesson, clear planning of the result of independent work, the choice of teaching and upbringing methods (Timpau, 2015). According to researchers, the capabilities of organizing and managing the independent work of students for increasing the training efficiency are great. The essence of independent activity is determined by the characteristics of cognitive tasks manifested in the specific content of individual works. In all the considered views on SIWT, its main defining feature is the fulfillment of tasks by students with the teacher's direct participation. This feature characterizes such work from the organizational point of view as a specific form of training (Jazuly et al., 2019). Thus, independent work with a teacher is the students' cognitive activity, motivated and consulted by a teacher and aimed at the students' professional formation through the development of their personal activity, interested participation in the implementation of the transition from education to professional activity (Gauta, 2014).

The study hypothesizes that if the student's independent work under the supervision of a foreign language teacher is organized on a systematic basis of its constant improvement, considering the specific features of technical specialties, then this will increase the cognitive independence of students, since such an organization will correspond to the changing realities of the labor market, thereby enhancing their educational motivation and educational activity in mastering foreign speech.

The goal of the study is to develop and scientifically substantiate the improvement of the organization of SIWT in the study of a foreign language at a technical university.

\section{Materials and methods}

The study was conducted based on two universities, the Karaganda Technical University (KTU) and Karaganda University named after E.A. Buketov (KarU), from September 2018 to May 2019, which was justified by the duration of two-semester studies at universities. We applied the following general scientific and special methods: the method of pairwise selection, the method of generalization, the method of comparison, the method of observation, the method of processing experimental data, the survey method, the method of evaluating the results of the study.

The pedagogical experiment consisted in the implementation of the developed methodology for teaching and was carried out to identify and compare diagnostic changes in the quality of the knowledge gained by students in SIWT classes using the new developed improvement methodology (Börü, 2018).

The survey was conducted to determine the current situation regarding the improvement of methods for organizing SIWT in a foreign language, the role of the functioning of classroom activities for students, and the differences in the studied forms of SIWT and the forms of organizing other types of classes (for example, students' independent work (SIW)). We prepared questionnaires (10 questions) on the importance of SIWT in the educational process in a professional foreign language and its organizational forms for students and university teachers. 
The questionnaire was taken by teachers of foreign languages from the KTU and KarU) 60 people), as well as students of the universities ( 500 people), using the methods described below.

To achieve the study goal, two types of methods for processing and describing the material under study were used - general scientific and special:

- The method of pairwise selection was used to select subjects, where two groups were selected in such a way that they were identical in neutral and control characteristics but had differences in factor characteristics. There were 118 people in the experimental group and 99 in the control group. This number of subjects helped to eliminate errors to achieve the most correct result. Both groups of subjects were divided into approximately the same number of people (it was not possible to make it the same, because the students were involved in full groups, and we could not change the academic composition of the groups, since all students had different but related specialties). The selection procedure for the full and reduced training option was the distribution of study groups according to their affiliation with the teacher, i.e. method of mechanical (systematic) sampling.

- The method of generalization was applied to form a new definition of SIWT. Previous variations of definitions were examined, matching and comparison were performed, and using the specified method, a definition of SIWT was given.

- The comparison method was used in the adaptation of the studied definition of SIWT in the field of teaching in universities.

- The observation method was used in the implementation of the formative experiment, to obtain general data and their fixation, which was studied when teaching university students to understand professional foreign language texts; at the same time, the necessary professionally significant strategies of cognitive and practical independence were formed (Bashir, Mattoo, 2012).

- The method of processing the experimental data was applied using a program for statistical analysis of Microsoft Excel data; in the standardization of the data obtained, graphical presentation of the results was used to visualize some of the studied aspects (tables, diagrams), as well as facilitate the perception and comparison of the initial, intermediate, and final indicators.

- The survey method, which was applied during the preliminary studies, to obtain the initial data of the starting point in the study.

- The method for assessing the results of students' activities when summing up the intermediate and final results of the experiment for unifying the data and raising them to a universal scale, as well as for analyzing the survey.

\section{Results}

The result indicates that all teachers interviewed note the use of SIWT classes to reiterate the educational material that was not mastered by students in the classroom.

These results are fundamental for the SIWT duplication theory and practical classroom studies because their goals are identical.

The results of the observation method indicate that when teaching students of technical specialties to understand POT in a foreign language, the necessary professionally significant strategies of cognitive and practical independence are formed.

The results of the questionnaire of students and teachers are presented in Table 1.

The obtained results of the study confirmed the validity of the hypothesis put forward that if the SIW under the supervision of a foreign language teacher is organized on a systematic basis of constant improvement, considering the specific features of technical specialties, then this will increase the students' cognitive independence since such a structure will correspond to the changing the realities of the labor market, thereby enhancing the students' educational motivation and educational activity in mastering a foreign language (Shaterloo, Mohammadyari, 2011).

During experimental teaching in the understanding of foreign language POT, the dependence of the formation level of the of cognitive-practical independence (CPI) strategies was determined, associated with the introduction of the teaching aid "Professional English in Metallurgy; Materials Science" that we developed into the educational process in a full and reduced version. 
Table 1. The results of the questionnaire to determine the situation of organizing SIW with a foreign language teacher according to the answers from intermediate sections (section 1 - the goals of SIWT; section 2 - the significance and organization of SIWT)

\begin{tabular}{|c|c|c|c|c|c|}
\hline \multirow[t]{2}{*}{ Goals of SIWT } & \multicolumn{2}{|l|}{ Section 1} & \multirow{2}{*}{$\begin{array}{l}\text { Significance and } \\
\text { organization of SIWT }\end{array}$} & \multicolumn{2}{|l|}{ Section 2} \\
\hline & $\begin{array}{l}\text { Students } \\
\text { (\%) }\end{array}$ & $\begin{array}{l}\text { Teachers } \\
\text { (\%) }\end{array}$ & & $\begin{array}{l}\text { Students } \\
\text { (\%) }\end{array}$ & $\begin{array}{l}\text { Teachers } \\
\text { (\%) }\end{array}$ \\
\hline $\begin{array}{l}\text { SIWT and practical } \\
\text { lessons are different }\end{array}$ & 67 & 70 & $\begin{array}{l}\text { Studying additional } \\
\text { material in SIWT } \\
\text { classes }\end{array}$ & 66 & 82 \\
\hline $\begin{array}{l}\text { SIWT and practical } \\
\text { lessons are identical }\end{array}$ & 33 & 30 & $\begin{array}{l}\text { Revising } \\
\text { material in } \\
\text { classes }\end{array}$ & 34 & 18 \\
\hline
\end{tabular}

The level of formation of CPI strategies for three groups of indicators was measured according to the same parameters in the control and experimental groups. The results of analyzing the indicators of the formation of the teaching staff strategies, presented in the full version of the training, are determined at the beginning of the course (Palloff, Pratt, 2011). Compliance with the basic requirements of the standard at the university was taken as a starting point - low level A1 (60-74 \%), average level A2-B1 (75-89\%), high level B2-C1 (90-100 \%) (Baumert et al., 2010).

When teaching students to understand foreign language POT in full, a positive trend is noted both in the experimental and in the control groups. The development of CPI strategies in the control group occurs within the framework of a traditional educational program through the improvement of reading skills (Dos Santos, 2019). In the experimental group, the formation of the level of strategies is faster and more dynamic, which confirms the efficiency of the methods.

At the diagnostic stage (conversation, questionnaire, testing, observation, expert assessments), some discrepancies were revealed between the indicators of the control (CG) and experimental groups (EG) (Table 2), although the conditions of experimental learning were the same.

We used the criterion of statistical analysis [chi-square test $x^{2}$ ] and also indicated the calculated values of the statistical test and the significance level $p$.

Data of the analysis of indicators for the formation of strategies of cognitive and practical independence at the beginning of the experiment, September 2018 (full version).

Table 2. Educational and information data of the CG and EG by levels

\begin{tabular}{|l|c|c|c|}
\hline \multirow{2}{*}{ Level } & \multicolumn{3}{|c|}{ Educational and information (criterion 1), \% } \\
\cline { 2 - 4 } & CG & EG & $\begin{array}{c}\text { Measure of Pearson's } \\
\text { deviation }\end{array}$ \\
\hline $\begin{array}{l}\text { B2-C1 } \\
\text { (90-100\%) }\end{array}$ & 1.22 & 5 & 2.85768 \\
\hline $\begin{array}{l}\text { A2-B1 } \\
(75-89 \%)\end{array}$ & 31.71 & 30 & 0.09747 \\
\hline $\begin{array}{l}\text { A1 } \\
(60-74 \%)\end{array}$ & 67.07 & & 0.065921538 \\
\hline
\end{tabular}




\begin{tabular}{|c|c|}
\hline d.f. (degree of freedom) & 2 \\
\hline$\chi^{2}$ & 3.021071538 \\
\hline$\chi^{2}{ }_{0.05 ; 2}$ (significance level) & 5.991464547 \\
\hline $\mathrm{p}$-value (p value) & 0.220791653 \\
\hline
\end{tabular}

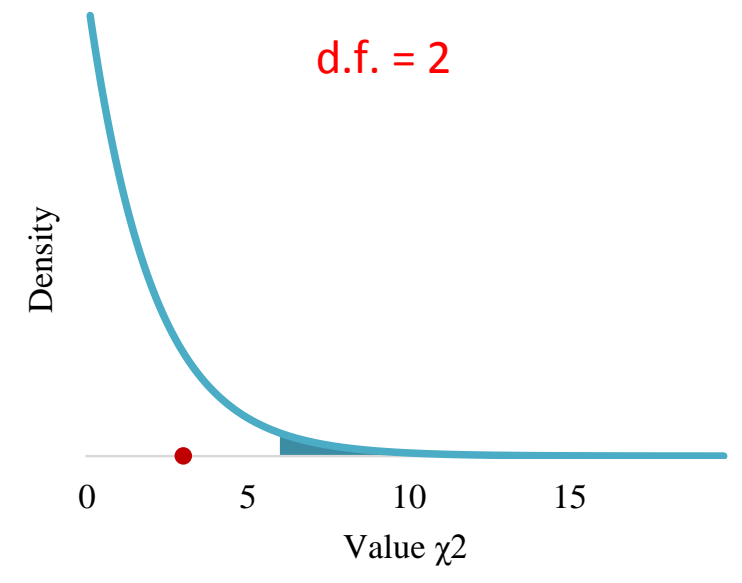

Fig. 1. Distribution of $\chi^{2}$

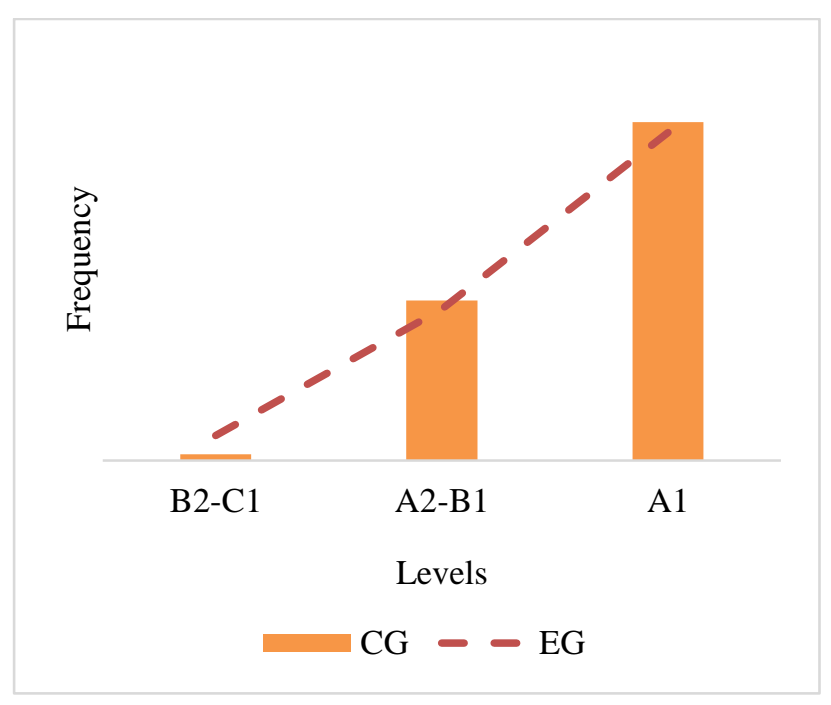

Fig. 2. Data of CG and EG by levels

Table 3. Compensatory data from the CG and EG by levels

\begin{tabular}{|c|c|c|c|}
\hline \multirow[b]{2}{*}{ Level } & \multicolumn{3}{|c|}{ Compensatory (criterion 2), \% } \\
\hline & CG & EG & $\begin{array}{c}\text { Measure of Pearson's } \\
\text { deviation }\end{array}$ \\
\hline $\begin{array}{l}\mathrm{B} 2-\mathrm{C} 1 \\
(90-100 \%)\end{array}$ & 3.66 & 5 & 0.35912 \\
\hline $\begin{array}{l}\mathrm{A} 2-\mathrm{B} 1 \\
(75-89 \%)\end{array}$ & 53.66 & 60 & 0.669926667 \\
\hline $\begin{array}{l}\mathrm{A} 1 \\
(60-74 \%)\end{array}$ & 42.68 & 35 & 1.685211429 \\
\hline \multicolumn{2}{|c|}{ d.f. (degree of freedom) } & \multirow{2}{*}{\multicolumn{2}{|c|}{$\begin{array}{r}2 \\
2.714258095\end{array}$}} \\
\hline \multicolumn{2}{|c|}{$x^{2}$} & & \\
\hline \multicolumn{2}{|c|}{$\frac{\lambda}{\chi^{2}{ }_{0.05 ; 2} \text { (significance level) }}$} & \multicolumn{2}{|r|}{5.991464547} \\
\hline \multicolumn{2}{|c|}{$\mathrm{p}$-value ( $\mathrm{p}$ value) } & \multicolumn{2}{|r|}{0.257398697} \\
\hline
\end{tabular}

The level of the students' mastery of CPI strategies in the process of implementing the full training was measured at the initial and final stages according to all criteria - educational and information, compensatory and independent and creative.

Measurements are made both by expert teachers and by the students who evaluate their own achievements (Simpson, 2018). Since the level of formed CPI strategies is measured, self-esteem plays an important role in learning, therefore, students are asked to analyze their own activities through conversations with the teacher and filling out questionnaires. The study showed that students' awareness of the need to form CPI strategies becomes the basis for self-management and self-control of their activities, which brings the students to the stage of creative implementation of the information extracted (Wong, Chiu, 2019). For example, the level of critical comprehension of 
the extracted information was established by assessing the students' logical conclusions after reading a foreign-language POT.

Table 4. Independent and creative data from the CG and EG by levels

\begin{tabular}{|l|c|c|r|}
\hline \multirow{2}{*}{ Level } & \multicolumn{3}{|c|}{ Independent and creative (criterion 3), \% } \\
\cline { 2 - 4 } & CG & EG & $\begin{array}{c}\text { Measure of Pearson's } \\
\text { deviation }\end{array}$ \\
\hline $\begin{array}{l}\text { B2-C1 } \\
\text { 90-100\%) }\end{array}$ & 1.22 & 5 & 2.85768 \\
\hline $\begin{array}{l}\text { A2-B1 } \\
(75-89 \%)\end{array}$ & 32.93 & 40 & 1.2496225 \\
\hline $\begin{array}{l}\text { A1 } \\
(60-74 \%)\end{array}$ & 65.85 & 55 & 2.140409091 \\
\hline \multicolumn{2}{|c|}{ d.f. (degree of freedom) } & & 2 \\
\hline \multicolumn{2}{|c|}{$\chi^{2}$ o.05; (significance level) } & & \\
\hline \multicolumn{2}{|c|}{ p-value (p value) } & & 5.247711591 \\
\hline
\end{tabular}

The students who have been trained in understanding foreign-language POT during implementing the full version continue their own independent studies to further receive and creatively implement the extracted information (Tables 5-9).

Table 5. Data of the level analysis of indicators for the formation of strategies of cognitive and practical independence at the end of the experiment (reduced training option)

\begin{tabular}{|c|c|c|c|c|c|c|c|}
\hline \multicolumn{2}{|c|}{ Level } & \multicolumn{2}{|c|}{$\begin{array}{c}\text { Educational and } \\
\text { information (criterion } \\
\text { 1), \% }\end{array}$} & \multicolumn{2}{|c|}{$\begin{array}{l}\text { Compensatory } \\
\text { (criterion 2), \% }\end{array}$} & \multicolumn{2}{|c|}{$\begin{array}{c}\text { Independent and } \\
\text { creative (criterion } \\
\text { 3), \% }\end{array}$} \\
\hline & & CG & EG & CG & EG & $\mathrm{CC}$ & EG \\
\hline \multicolumn{2}{|c|}{ B2-C1 (90-100 \%) } & 10.9 & 15 & 10.9 & 15 & 13.85 & 20 \\
\hline \multicolumn{2}{|c|}{$\mathrm{A} 2-\mathrm{B} 1(75-89 \%)$} & 70.98 & 80 & 71.53 & 80 & 64.54 & \multirow{2}{*}{$\begin{array}{l}75 \\
5\end{array}$} \\
\hline \multicolumn{2}{|l|}{$\mathrm{A} 1(60-74 \%)$} & 18.12 & 5 & 17.57 & \multirow{2}{*}{\multicolumn{2}{|c|}{$\begin{array}{l}5 \\
\text { evel (p) }\end{array}$}} & \\
\hline \multicolumn{7}{|c|}{ Statistical test values and significance level (p) } & \\
\hline \multicolumn{3}{|c|}{$\begin{array}{l}\text { Educational and information } \\
\text { (criterion 1) }\end{array}$} & \multicolumn{2}{|c|}{ Compensatory (criterion 2) } & \multicolumn{3}{|c|}{$\begin{array}{l}\text { Independent and creative } \\
\text { (criterion 3) }\end{array}$} \\
\hline$\chi^{2}$ & \multicolumn{2}{|c|}{36.56455167} & $\chi^{2}$ & $37 \cdot 34224792$ & \multicolumn{2}{|l|}{$\chi^{2}$} & $\begin{array}{l}58.52836 \\
633\end{array}$ \\
\hline $\begin{array}{l}\chi^{2} 0.05 ; 2 \\
\text { (significance } \\
\text { level) }\end{array}$ & \multicolumn{2}{|c|}{5.991464547} & $\begin{array}{l}\chi^{2} \text { o.o5; } 2 \\
\text { (significance } \\
\text { level) }\end{array}$ & $5 \cdot 991464547$ & \multicolumn{2}{|c|}{$\begin{array}{l}\chi^{2} 0.05 ; 2 \\
\text { (significance } \\
\text { level) }\end{array}$} & $\begin{array}{l}5.991464 \\
547\end{array}$ \\
\hline $\begin{array}{l}\text { p-value } \\
\text { (p value) }\end{array}$ & \multicolumn{2}{|c|}{$1.14844 \mathrm{E}-08$} & $\begin{array}{l}\mathrm{p} \text {-value } \\
\text { (p value) }\end{array}$ & 7.78456E-09 & \multicolumn{2}{|c|}{$\begin{array}{l}\text { p-value } \\
\text { (p value) }\end{array}$} & $\begin{array}{l}1.95311 \mathrm{E}- \\
13\end{array}$ \\
\hline
\end{tabular}


Table 6. Data of the level analysis of indicators for the formation of strategies of cognitive and practical independence at the end of the experiment (full training option)

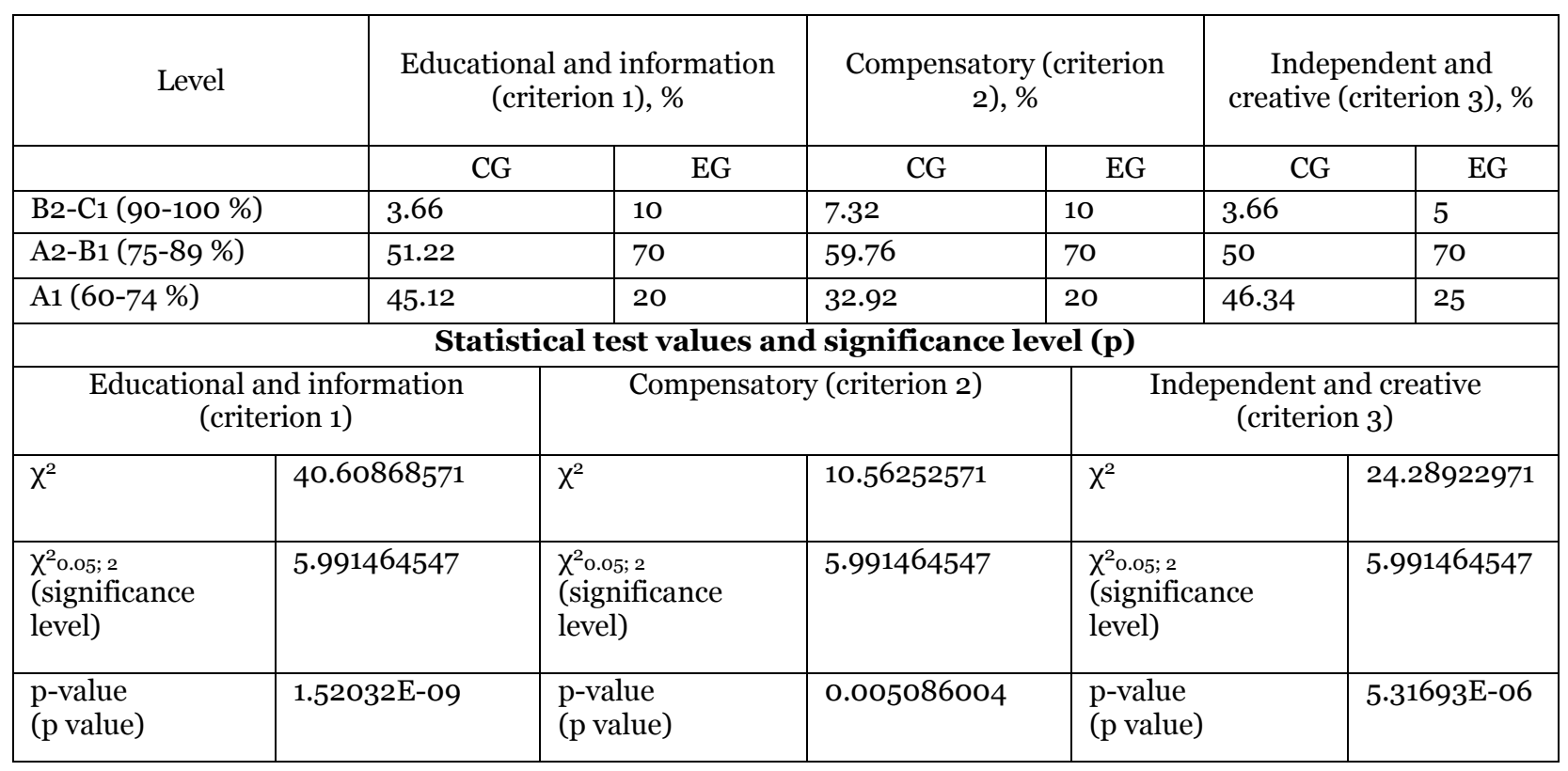

Table 7. Indicators of self-assessment by students of their level of mastery of strategies of cognitive and practical independence at the end of the experiment (reduced training option)

\begin{tabular}{|c|c|c|c|c|c|c|c|c|}
\hline \multirow{2}{*}{\multicolumn{2}{|c|}{ Level }} & \multicolumn{3}{|c|}{$\begin{array}{c}\text { Educational and } \\
\text { information (criterion 1), } \\
\%\end{array}$} & \multicolumn{2}{|c|}{$\begin{array}{l}\text { Compensatory } \\
\text { (criterion 2), \% }\end{array}$} & \multicolumn{2}{|c|}{$\begin{array}{c}\text { Independent and } \\
\text { creative (criterion 3), \% }\end{array}$} \\
\hline & & \multicolumn{2}{|l|}{ CG } & EG & CG & EG & CG & EG \\
\hline \multicolumn{2}{|c|}{$\mathrm{B} 2-\mathrm{C} 1(90-100 \%)$} & \multicolumn{2}{|l|}{5.10} & 13 & 4.22 & 14 & 29.27 & 15 \\
\hline \multicolumn{2}{|c|}{ A2-B1 (75-89\%) } & \multicolumn{2}{|l|}{74.29} & 81 & 75.05 & 79 & 51.22 & 75 \\
\hline A1 (60-74 \%) & & 20.61 & & 6 & 20.73 & 7 & 19.51 & 10 \\
\hline \multicolumn{9}{|c|}{ Statistical test values and significance level (p) } \\
\hline \multicolumn{3}{|c|}{$\begin{array}{l}\text { Educational and information } \\
\text { (criterion 1) }\end{array}$} & \multicolumn{3}{|c|}{ Compensatory (criterion 2) } & \multicolumn{3}{|c|}{$\begin{array}{l}\text { Independent and creative } \\
\text { (criterion 3) }\end{array}$} \\
\hline$\chi^{2}$ & \multicolumn{2}{|c|}{40.93197232} & $\chi^{2}$ & & 33.95994286 & \multicolumn{2}{|l|}{$x^{2}$} & 30.159382 \\
\hline $\begin{array}{l}\chi^{2}{ }_{0.05 ; 2} \\
\text { (significance } \\
\text { level) }\end{array}$ & \multicolumn{2}{|c|}{$5 \cdot 991464547$} & $\begin{array}{l}\chi^{2} \text { o. } \\
\text { (sig } \\
\text { lev }\end{array}$ & $\begin{array}{l}5 ; 2 \\
\text { l) } \\
\text { l) }\end{array}$ & 5.991464547 & \multicolumn{2}{|c|}{$\begin{array}{l}\chi^{2} \text { o.o5; } 2 \\
\text { (significance } \\
\text { level) }\end{array}$} & 5.991464547 \\
\hline $\begin{array}{l}\mathrm{p} \text {-value } \\
\text { (p value) }\end{array}$ & \multicolumn{2}{|c|}{$1.29341 \mathrm{E}-09$} & $\begin{array}{l}\mathrm{p}-\mathrm{v} \\
(\mathrm{p})\end{array}$ & $\begin{array}{l}\text { lue } \\
\text { alue) }\end{array}$ & $4.22369 \mathrm{E}-\mathrm{O} 8$ & \multicolumn{2}{|c|}{$\begin{array}{l}\mathrm{p} \text {-value } \\
\text { (p value) }\end{array}$} & $2.82471 \mathrm{E}-07$ \\
\hline
\end{tabular}

Table 8. Indicators of self-assessment by students of their level of mastery of strategies of cognitive and practical independence at the end of the experiment (full training option)

\begin{tabular}{|l|l|l|l|l|l|l|}
\hline \multirow{2}{*}{ Level } & \multicolumn{2}{|l|}{$\begin{array}{l}\text { Educational and } \\
\text { information } \\
\text { (criterion 1), \% }\end{array}$} & \multicolumn{2}{l|l}{$\begin{array}{l}\text { Compensatory } \\
\text { (criterion 2), \% }\end{array}$} & \multicolumn{2}{l|}{$\begin{array}{l}\text { Independent and } \\
\text { creative } \\
\text { (criterion 3), \% }\end{array}$} \\
\hline & CG & EG & CG & EG & CG & EG \\
\hline B2-C1 (90-100 \%) & 4.88 & 5 & 10.9 & 15 & 3.66 & 5 \\
\hline
\end{tabular}




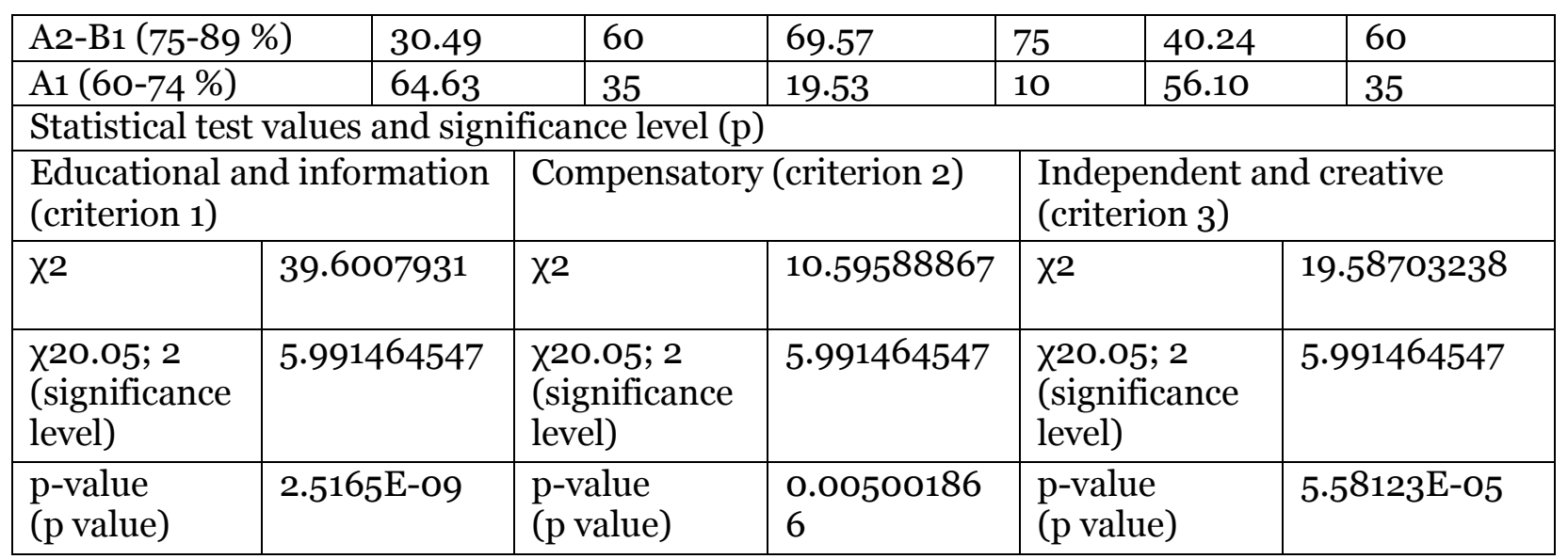

The results of the experimental work are presented in Table 9, reflecting the total indicators of the formation of educational information, compensation, and self-creative strategies (Table 9).

Table 9. Indicators of the dynamics of the formation of teaching staff strategies at different levels at the beginning and end of the experiment

\begin{tabular}{|c|c|c|c|c|c|}
\hline \multirow[b]{3}{*}{$\begin{array}{l}\text { Criteria total } \\
\text { indicators }\end{array}$} & \multirow[b]{3}{*}{ Level } & \multicolumn{4}{|c|}{ Manifestation in students (\%) } \\
\hline & & \multicolumn{2}{|c|}{ EG } & \multicolumn{2}{|c|}{ CG } \\
\hline & & $\begin{array}{l}\text { Beginnin } \\
\text { g of } \\
\text { experime } \\
\text { nt }\end{array}$ & $\begin{array}{c}\text { End of } \\
\text { experiment }\end{array}$ & $\begin{array}{l}\text { Beginning of } \\
\text { experiment }\end{array}$ & $\begin{array}{c}\text { End of } \\
\text { experime } \\
\text { nt }\end{array}$ \\
\hline \multirow{3}{*}{$\begin{array}{l}\text { Educational } \\
\text { and } \\
\text { information }\end{array}$} & $\mathrm{B} 2-\mathrm{C} 1(90-100 \%)$ & 5 & 15 & 1.22 & 10.9 \\
\hline & $\mathrm{A} 2-\mathrm{B} 1(75-89 \%)$ & 30 & 80 & 31.71 & 70.98 \\
\hline & A1 (60-74 \%) & 65 & 5 & 67.07 & 18.12 \\
\hline \multirow{3}{*}{$\begin{array}{l}\text { Compensator } \\
\text { y }\end{array}$} & B2-C1 (90-100 \%) & 5 & 15 & 3.66 & 10.9 \\
\hline & A2-B1 (75-89 \%) & 60 & 80 & 53.66 & 71.53 \\
\hline & A1 (60-74 \%) & 35 & 5 & 42.68 & 17.57 \\
\hline \multirow{3}{*}{$\begin{array}{l}\text { Independent } \\
\text { and creative }\end{array}$} & B2-C1 (90-100 \%) & 5 & 20 & 1.22 & 13.85 \\
\hline & A2-B1 (75-89\%) & 40 & 75 & 32.93 & 64.54 \\
\hline & $\mathrm{A} 1(60-74 \%)$ & 55 & 5 & 65.85 & 21.61 \\
\hline
\end{tabular}

To confirm the reliability of the differences, we will use the formula for comparing the initial criteria "High", "Average", "Low" in the EG and CG. The data shows that the criteria are different, when comparing the initial and final ratios, we get the following data:

- among all types of criteria in the high-level groups, the percentage of those who have mastered the criteria has increased but in CG the percentage data has a more positive trend;

- in the average-level groups, the percentage of those who have mastered the criteria also increased, and in the CG the percentage data also have higher indicators;

- in groups with a low level of knowledge, the percentage of those who have mastered the criteria has noticeably decreased, and the data in EG and CG are almost identical (Bichi, 2015).

The reliability and validity of the research results are ensured by the consistency of the initial methodological foundations, the use of a set of scientific methods adequate to the subject, purpose and objectives of the research, the representativeness of the sample of participants in the experimental work and the analysis of the results of experimental data.

The results of the experimental work show that in the course of teaching students of technical specialties to understand foreign language POT, the necessary professionally significant CPI strategies are formed. 


\section{Discussion}

We believe that SIWT, while being an efficient means of forming the professional competence in future specialists and a multidimensional pedagogical phenomenon, at the same time acts as one of the integral, organic elements of the educational process, a sub-process of a holistic educational process in an institution of higher professional education; as a type of educational activity, in which tasks of an educational, research, professional nature are independently performed, ensuring the assimilation of a system of professional knowledge, methods of activity, the formation of skills and abilities of creative activity (Bronson, 2016); as self-organization of educational activity characterized by increasing internal motivation, independence, activity of the student as its subject; as the teacher's way of managing independent cognitive activity of students, a means of its logical and psychological organization; and its result is a readiness for self-fulfillment in professional activity (Castilla et al., 2017).

As a complex pedagogical phenomenon, SIWT in its organization, in our opinion, requires one to rely on clear rules - management principles, the application of which will clearly design the independent cognitive activity of students (Adeoye, 2016).

In pedagogical management regarding SIWT, it is also important to observe the principle of unity of three interrelated forms of the students' independent work (extracurricular independent work; classroom-based independent work, which is carried out under the direct supervision of a teacher; creative, including research work, the feedback principle in the system of cooperation between students and the teacher, the principle of communicative interaction in relation to the one created by students in the process of independent work of students under the guidance of a teacher, as well as the rating method of control and a gradual transition from teacher control to self-control, the principle of conformity of the assessment of the educational result to the set goal (Filippello et al., 2019, 2019).

We found a statement on the above data in the work by Stefano I. Di Domenico, Marc A. Fournier (Di Domenico, Fournier, 2015), who emphasize that "intelligence, conscientiousness and self-motivation" are well-established predictors of academic work, which was confirmed by our research according to the results of a survey and questionnaire of students and faculty.

Thus, the study and the results obtained allow us to believe that we have developed and substantiated the improvement of the organization of SIWT when studying a foreign language at a technical university.

\section{Conclusion}

We considered the students' practical classroom-based work in technical specialties under the teacher's supervision in the study of a foreign language and introduced a methodology for improving the organization of SIWT in the study of a foreign language in a technical university.

The hypothesis stating that if the SIWT in a foreign language is organized on a systematic basis of its constant improvement, considering the features of technical specialties, then this will increase the students' cognitive independence since such an organization will correspond to the changing realities of the labor market, thereby enhancing the students' educational motivation and educational activity in mastering foreign speech, is confirmed by the results of the study.

The analysis of the results of the experimental work showed that, in comparison with the students of the CG, the students of the EG at the substantive and procedural levels of activities for the formation of strategies for understanding foreign-language POT:

- in the educational and information aspect, mastered the strategies of understanding foreign language POT through the implementation of certain exercises in SIWT classes; have a high degree of cognitive activity in extracting professionally significant information, strive for selfmanagement of their activities, exercise self-control; know the peculiarities of the style of scientific prose, the features of POT;

- in a compensatory aspect, the students can convert the knowledge gained at the stages of forming strategies for understanding foreign language POT in SIWT lessons, methodological instructions from step-by-step management of understanding into CPI for the extraction and further use of professionally valuable information; are aware of the linguistic, cultural professional value of foreign-language POTs; could assess whether the students knew the facts learned, how well the students knew them, and whether the students needed this information at all (Wurf, 2018);

- in an independent and creative aspect, the students have a high level of intention for cognitive and practical activities; know how to competently use certain strategies of understanding 
for a specific text; easily carry out reflection operations on understanding POT; critically evaluate the extracted information, show interest in transferring the acquired CPI skills to creative areas of professional activity.

It can be concluded that the relationship between the goals and objectives of organizing students' independent work under the guidance of a foreign language teacher with the goals and objectives of future professional activity, the unifying component of which is the formation of cognitive professionalactive independence (Brinkworth et al., 2017; Yamagata-Lynch et al., 2015); the knowledge of the structural components of the educational language environment, the creation of pedagogical conditions for the formation of independence allows one to move from modeling a given environment to its implementation; the formation of the skills and abilities of independent work of students in a foreign language under the guidance of a teacher is a prerequisite for the efficient organization of a student's independent cognitive activity and integration into the world community in the context of continuous foreign language education; the "methodology for organizing independent work of students of technical specialties under the guidance of a teacher for teaching a foreign language" should be understood as a set of methods, means and forms of teaching that allow the teacher to design independent work of students, developing their cognitive active activity, forming the research skills of students for the independent achievement of practical goals (Thomas et al., 2015); the implementation of the methodology of SIWT contributes to the transformation of students' educational independence into the autonomy of educational activities for mastering the target language, which leads to higher academic performance and, ultimately, to an increase in the quality of education.

\section{Acknowledgments}

All authors made equal contributions to the concept and design of the study.

\section{References}

Adeoye, 2016 - Adeoye, E.A. (2016). Relationship between the counsellor and other school guidance personnel. In A.I. Idowu (ed.). Guidance and Counselling in Education (pp. 164-189). Ilorin: Indemac.

Ayodele, Adebiyi, 2013 - Ayodele, C., Adebiyi, D. (2013). Study habits as influence of academic performance of university undergraduates in Nigeria. Research Journal in organizational Psychology \& Educational Studies. 2(3): 72-75.

Bashir, Mattoo, 2012 - Bashir, I., Mattoo, N.H. (2012). A study on study habits and academic performance among adolescents (14-19) years. International Journal of Social Science Tomorrow. 1(5): $1-5$.

Baumert et al., 2010 - Baumert, J., Kunter, M., Blum, W., Brunner, M., Voss, T., Jordan, A., Klusmann, U., Krauss, S., Neubrand, M., Tsai, Y.-M. (2010). Teachers' mathematical knowledge, cognitive activation in the classroom, and student progress. American Educational Research Journal. 47(1): 133-180. DOI: 10.3102/0002831209345157

Bichi, 2015 - Bichi, A.A. (2015). Analysis of UTME and post-UTME scores of education students at Northwest University Kano-Nigeria. 1st International Conference on Education, Beijing, China, April 9.

Börü, 2018 - Börü, N. (2018). The Factors Affecting Teacher-Motivation. International Journal of Instruction. 11(4): 761-776. DOI: 10.12973/iji.2018.11448a

Brinkworth et al., 2017 - Brinkworth, M.E., Mcintyre, J., Juraschek, A.D., Gehlbach, H. (2017). Teacher-student relationships: The positives and negativesof assessing both perspectives. Journal of applied developmental psychology . 55: 24-38.

Bronson, 2016 - Bronson, S. (2016). Autonomy support environment and autonomous motivation on nursing student academic performance: an exploratory analysis. Nurse Education Today. 44: 103-108.

Castilla et al., 2017 - Castilla, N., Llinares, C., Bravo, J.M., Blanca, V. (2017). Subjective assessment of university classroom environment. Building and Environment. 122: 72-81. DOI: 10.1016/j.buildenv.2017.06.004

Di Domenico, Fournier, 2015 - Di Domenico, S.I., Fournier, M.A. (2015). Able, ready, and willing: examining the additive and interactive effects of intelligence, conscientiousness, and autonomous motivation on undergraduate academic performance. Learning and Individual Differences. 40: 156-162. DOI: 10.1016/j.lindif.2015.03.016 
Dos Santos, 2019 - Dos Santos, L.M. (2019a). English language learning for engineering students: Application of a visual-only video teaching strategy. Global Journal of Engineering Education. 21(1): 37-44.

Filippello et al., 2019 - Filippello, P., Buzzai, C., Costa, S., Orecchio, S., Sorrenti, L. (2019). Teaching style and academic achievement: The mediating role of learned helplessness and mastery orientation. Psychology in the Schools. 57(5): 5-16.

Gauta, 2014 - Gauta, M.D. (2014). Impact of guidance and counselling service on students social and emotional adjustment in public urban and rural secondary schools in Nakuru and Uasin Gishu countries, Kenya. International Journal of Science and Research. 3(11): 431-438.

Jazuly et al., 2019 - Jazuly, A., Indrayani, N., Prystiananta, N.C. (2019). The teaching of English in Indonesian primary school: A response to the new policy. Linguistic, English Education and Art Journal. 3(1): 17-25. DOI: 10.31539/leea.v3i1.609

Lou et al., 2012 - Lou, S.J., Chung, C.C., Dzan, W.Y., Shih, R.C. (2012). Construction of a creative instructional design model using blended, project-based learning for college students. Creative Education. 3(7): 1281-1290. DOI: 10.4236/ce.2012.37187

Mendezabal, 2013 - Mendezabal, M.J.N. (2013). Study habits and attitudes: The road to academic success. Open Science Repository Education. Online (open-access), e70081928. DOI: 10.7392/Education.70081928

Mutsotso, Abenga, 2010 - Mutsotso, S., Abenga, E. (2010). Study methods for improving quality learning and performance in higher education. Educational Research and Reviews. 5(12): 808-813.

Palloff, Pratt, 2011 - Palloff, R.M., Pratt, K. (2011). The excellent online instructor strategies for professional development. San Francisco, CA: Jossey-Bass.

Samuelson, Litzler, 2016 - Samuelson, C.C., Litzler, E. (2016). Community cultural wealth: An assets-based approach to persistence of engineering students of color. Journal of Engineering Education. 105(1): 93-117. DOI: 10.1002/jee.20110

Sharok, 2018 - Sharok, V.V. (2018). Emotsional'no-motivatsionnye faktory udovletvorennosti obucheniem v vuze [Emotional and motivational factors o satisfaction with university education]. Sibirskii psikhologicheskii zhurnal. 69: 33-45. DOI: 10.17223/17267080/69/2 [in Russian]

Shaterloo, Mohammadyari, 2011 - Shaterloo, A., Mohammadyari, G. (2011). Students counselling and academic achievement. Procedia - Social and Behavioral Sciences. 30: 625-628. DOI: $10.1016 /$ j.sbspro.2011.10.121

Simpson, 2018 - Simpson, O. (2018). Supporting students in online, open and distance learning. London: Routledge.

Timpau, 2015 - Timpau, C. (2015). The teacher's role in building the student's range of autonomy. Procedia - Social and Behavioral Sciences. 203: 22-27. DOI: 10.1016/j.sbspro.2015.08.254

Thomas et al., 2015 - Thomas, L., Hockings, C., Ottaway, J., Jones, R. (2015). Independent learning: Student perspectives and experiences. Final report to the Higher Education Academy. York: Higher Education Academy. [Electronic resource]. URL: https://www.heacademy.ac.uk/ sites/default/files/independent_learning_final.pdf (date of access: 15.11.2017).

Wong, Chiu, 2019 - Wong, B., Chiu, Y.L. (2019). Swallow your pride and fear: The educational strategies of highachieving non-traditional university students. British Journal of Sociology of Education. 40(7): 868-882. DOI: 10.1080/01425692.2019.1604209

Wurf, 2018 - Wurf, G.C. (2018). Culture and personality in international schools: are trait differences in students' personalities attenuated or amplified. Intercultural Education. 29(3): 418-433.

Yamagata-Lynch et al., 2015 - Yamagata-Lynch, L.C., Do, J., Skutnik, A.L., Thompson, D.J., Stephens, A.F., Tays, C.A. (2015). Design lessons about participatory self-directed online learning in a graduate-level instructional technology course. Open Learning: The Journal of Open, Distance and e-Learning. 30(2): 178-189. DOI: 10.1080/02680513.2015.1071244

Zein, 2017 - Zein, M.S. (2017). Elementary English education in Indonesia: Policy developments, current practices, and future prospects: How has Indonesia coped with the demand for teaching English in schools? English Today. 33(1): 53-59. DOI: 10.1017/s0266078416000407 